\title{
SORPCJA CHROMU (VI) NA MODYFIKOWANYCH ZEOLITACH NATURALNYCH
}

\begin{abstract}
Celem badań było wyznaczenie równowagi sorpcji jonów chromu (VI) z roztworów wodnych na modyfikowanych zeolitach naturalnych pochodzących z Włoch i USA. Do syntezy organo-zeolitów zastosowano HDTMA-Br w ilości dwukrotnej pojemności kationowymiennej zeolitów (2,0 ECEC). Badania przeprowadzono w warunkach nieprzepływowych przy odczynie $\mathrm{pH}$ równym 3,0; 4,0 i 5,0 w temperaturze pokojowej. Największą efektywność sorpcji jonów Cr(VI) uzyskano dla chabazytu przy $\mathrm{pH}=4$ i uziarnienia poniżej $0,25 \mathrm{~mm}$, kiedy w roztworze dominowały jony wodorochromianowe HCrO4-.
\end{abstract}

Słowa kluczowe: sorpcja, modyfikacja, zeolity, organo-zeolity, chrom (VI), HDTMA

\section{Wstęp}

Wiele gałęzi przemysłu wykorzystuje chrom w różnych procesach przemysłowych, w szczególności w handlu i obróbce metali, garbarstwie, galwanizacji, produkcji farb i wyrobów chemicznych, w przemyśle fotograficznym, w zakładach lotniczych oraz przemyśle samochodowym $[8,19,10]$. Na skutek tych działań jony chromu obecne w ściekach, odpadach, opadach atmosferycznych i zanieczyszczeniach gazowych wprowadzane są do wody i gleby, a tym samym do roślin, zwierząt i ludzi stanowiąc znaczące źródło emisji do środowiska.

Podwyższone zawartości chromu w środowisku naturalnym nie są obojętne dla zdrowia i życia ludzi oraz rozwoju biotycznej części środowiska [14]. Chrom trójwartościowy w niskich stężeniach jest pierwiastkiem niezbędnym dla funkcjonowania organizmu żywego [17]. W wyższych stężeniach może wywołać poważne zmiany immunologiczne w organizmach ssaków [6]. Chrom (VI) cechuje się wysoką toksycznością, wykazuje też działania mutagenne, teratogenne i kancerogenne, najczęściej powoduje raka płuc [1]. Najczęściej w środowisku naturalnym występuje w formie anionów: takich jak: $\mathrm{H}_{2} \mathrm{CrO}_{4}^{-}, \mathrm{Cr}_{2} \mathrm{O}_{7}{ }^{2-}, \mathrm{HCrO}_{4}^{-}$i $\mathrm{CrO}_{4}{ }^{2-}$.

\footnotetext{
${ }^{1}$ Autor do korespondencji: Paulina Sobolewska, Politechnika Rzeszowska, Zakład Oczyszczania i Ochrony Wód, Wydział Budownictwa, Inżynierii Środowiska i Architektury, 35-959 Rzeszów, al. Powstańców Warszawy 12, tel. + 48 (017) 743 2381, e-mail: psobolew@ prz.edu.pl
} 
Najwyższe dopuszczalne stężenie chromu ogólnego w wodzie przeznaczonej do spożycia w Polsce wynosi $0,05 \mathrm{mg} / \mathrm{dm}^{3}$, a $\mathrm{Cr}(\mathrm{VI})-0,02 \mathrm{mg} / \mathrm{dm}^{3}[11,12,13]$.

Konwencjonalnymi metodami stosowanymi do usuwania jonów metali ze środowiska wodnego są chemiczne strącanie, wymiana jonowa, wydzielanie elektrochemiczne, separacja membranowa, adsorpcja oraz filtracja membranowa [7]. Większość z tych metod jest efektywna, ale droga i często wymaga zachowania ścisłych reżimów technologicznych. Metody oparte na zjawisku sorpcji są uznawane nie tylko za skuteczne, ale też za selektywne. Powszechnie stosowanymi sorbentami są węgle aktywne i syntetyczne wymieniacze jonowe. Materiały te są drogie i mało selektywne, zatem ich zastosowanie w procesach oczyszczania wody, ścieków czy remediacji gleb, jest ekonomicznie nieopłacalne. W związku z tym coraz większe jest zainteresowanie materiałami alternatywnymi wykazującymi duże powinowactwo do jonów $\mathrm{Cr}(\mathrm{VI})$ [4].

Zeolity naturalne są to mikroporowate minerały glinokrzemianowe, charakteryzujące się strukturą kanalikową połączonych ze sobą wierzchołkami tetraedrów $\mathrm{SiO}_{4} \mathrm{i}_{\mathrm{AlO}}{ }_{4}^{-}$, powodujących ujemny ładunek powierzchni zewnętrznej. Specyficzna budowa sprawia, że mogą sorbować cząsteczki o ładunku dodatnim. Istnieje jednak możliwość chemicznej modyfikacji powierzchni zewnętrznej w celu przystosowania jej do sorpcji również cząsteczek naładowanych ujemnie [15]. Proces ten polega na wymianie naturalnych kationów $\mathrm{Ca}^{2+}, \mathrm{Mg}^{2+}, \mathrm{Na}^{+}, \mathrm{K}^{+}$występujących na pozycjach jonowymiennych na kationy organiczne, pochodzące z czwartorzędowych soli amoniowych takich, jak na przykład bromek heksadecylotrimetyloamoniowy (HDTMA-Br) w celu zwiększenia powinowactwa powierzchni zeolitu w stosunku do naładowanych ujemnie jonów.

Celem przeprowadzonych badań była modyfikacja dwóch różnych materiałów zeolitowych w celu uzyskania efektywnego sorbenta jonów $\mathrm{Cr}(\mathrm{VI})$. Określono wpływ uziarnienia materiałów sorpcyjnych, rodzaj materiału zeolitowego oraz odczynu $\mathrm{pH}$ roztworu $\mathrm{Cr}(\mathrm{VI})$ na efektywność jego sorpcji. Ponadto przeprowadzono modelowanie izoterm procesu sorpcji $\mathrm{Cr}(\mathrm{VI})$.

\section{Metodyka badań}

Do badań użyte zostały dwa materiały zeolitowe: chabazyt i filipsyt pochodzące odpowiednio z Włoch (kopalnia Italiana Zeoliti) i USA (kopalnia Saint Cloud). Wydzielone z surowej skały koncentraty zeolitowe składały się z:

- Chabazyt: chabazyt 54\% wag., klinoptylolit 36\% wag., kwarc 5\% wag., niezidentyfikowany zeolit $5 \%$ wag.,

- Filipsyt: filipsyt $29 \%$ wag., chabazyt $27 \%$ wag., plagioklaz $15 \%$ wag., skaleń $13 \%$ wag., grupy illitu i smektytu $8 \%$ wag., kalcyt $6 \%$ wag., kwarc $2 \%$ wag.

$\mathrm{Z}$ tufów zeolitowych wyodrębniono frakcję $0,25-1,0 \mathrm{~mm}$ dla chabazytu oraz $<0,25 \mathrm{~mm}$ dla obu materiałów. Zewnętrzna pojemność kationowymienna (ECEC) wyznaczona metodą spektroskopową (stężenie heksaminy kobaltowej) wynosiła odpowiednio 0,2625 i $0,1174 \mathrm{mmol} / \mathrm{g}$. 
Przed przystąpieniem do modyfikacji zeolity poddano aktywacji 3\% roztworem $\mathrm{NaCl}$ celem uzyskania formy sodowej. W tym celu odważono $50 \mathrm{~g}$ materiału zeolitowego, zalano $250 \mathrm{ml}$ roztworu chlorku sodu i wytrząsano mechanicznie przez 45 minut. Proces ten powtórzono kilkukrotnie, po czym materiał pozostawiano na około $20 \mathrm{~h}$. Po tym czasie materiały umieszczono w celulozowych membranach do dializy, celem wypłukania jonów $\mathrm{Cl}^{-}$na zasadzie osmozy. Zawartość jonów chlorkowych oznaczono metodą Mohra (norma PN-ISO 9297:1994.). Po osiągnięciu wartości chlorków poniżej $30 \mathrm{mg} / \mathrm{dm}^{3}$ materiały wysuszono.

Do modyfikacji zeolitów użyto bromku heksadecylotrimetyloamoniowego (HDTMA-Br) w ilości odpowiadającej 2,0 ECEC pojemności kationowymiennej zeolitów. Zeolity w formie Na umieszczono w zlewce $\mathrm{z}$ wodą demineralizowaną i mieszano przez $1 \mathrm{~h} \mathrm{w}$ stałej temperaturze $\mathrm{z}$ wykorzystaniem metody ultradźwiękowej. Do suspensji dodawano porcjami roztwór HDTMA-Br. Następnie materiał płukano celem odmycia nadmiaru HDTMA-Br i suszono w temp. $105^{\circ} \mathrm{C}$ przez $8 \mathrm{~h}$.

Uzyskane organo-zeolity użyto do sorpcji $\mathrm{Cr}(\mathrm{VI})$. W polipropylenowych probówkach o poj. $50 \mathrm{ml}$ umieszczono $0,2 \mathrm{~g}$ orano-zeolitu oraz $20 \mathrm{ml}$ roztworu przygotowanego poprzez rozpuszczenie odpowiedniej naważki soli $\mathrm{K}_{2} \mathrm{Cr}_{2} \mathrm{O}_{7}$ w wodzie dejonizowanej. Zakres początkowych stężeń roztworów dobrano tak, aby otrzymać pełny zakres izoterm $\left(1-1500 \mathrm{mg} / \mathrm{dm}^{3}\right)$.

Odczyn $\mathrm{pH}$ roztworów modelowych korygowano za pomocą $\mathrm{HNO}_{3}$ do wartości odpowiadającej $\mathrm{pH}_{\text {init }}=3,0,4,0$ oraz 5,0 . Tak przygotowane próbki wytrząsano mechanicznie (wytrząsarka orbitalna JWElectronic WL-2000) do momentu ustalenia się stanu równowagi $(24 \mathrm{~h})$.

Po tym czasie oddzielono fazę ciekłą od fazy stałej przy pomocy filtrów strzykawkach (PES 0,2um/33mm). Roztwór poddano analizie stężenia $\mathrm{Cr}(\mathrm{VI}) \mathrm{C}_{\mathrm{e}} \mathrm{me}-$ todą spektrometrii emisyjnej ze wzbudzeniem w plazmie indukcyjnie sprzężonej (ICP-OES, Integra XL - GBC Scientific Equipment). Analizę Cr(VI) wykonano przy długości fali $283,56 \mathrm{~nm}$.

\section{Wyniki i dyskusja}

\subsection{Wpływ wielkości uziarnienia materiałów sorpcyjnych na efektywność sorpcji $\mathbf{C r}(\mathrm{VI})$}

Na rysunku 1 przedstawiono wyniki wpływu wielkości uziarnienia materiałów na efektywność sorpcji, przeprowadzone dla chabazytu o wielkości uziarnienia $0,25-1$ oraz $<0,25 \mathrm{~mm}$. Zakres stężeń roztworów $\mathrm{Cr}(\mathrm{VI})$ mieścił się w przedziale od 0,5 do $1500 \mathrm{mg} / \mathrm{dm}^{3}$, natomiast początkowy odczyn $\mathrm{pH}$ był równy 4,0 . 


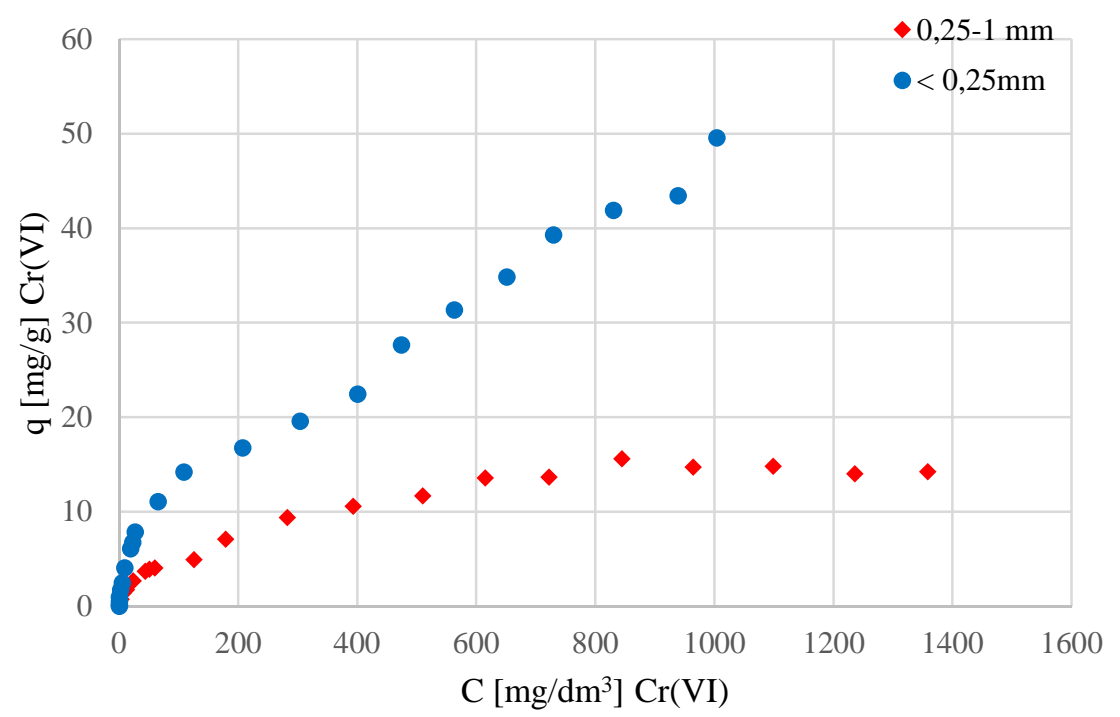

Rys. 1. Wpływ wielkości uziarnienia na efektywność sorpcji Cr(VI) na chabazycie

Fig. 1. Influence of grain size on the effectiveness of the sorption of $\mathrm{Cr}(\mathrm{VI})$ on the chabazite

Jak widać efektywność sorpcji dla materiału o mniejszym uziarnieniu jest większa. Maksymalna pojemność sorpcyjna $\left(\mathrm{q}_{\mathrm{m}, \mathrm{exp}}\right)$ wynosi odpowiednio $49,61 \mathrm{mg} / \mathrm{g}$ dla wielkości uziarnienia $<0,25 \mathrm{~mm}$, oraz 15,62 mg/g dla frakcji $0,25-1 \mathrm{~mm}$. Zatem maksymalna pojemność sorpcyjna dla chabazytu o mniejszych wymiarach ziaren była ponad trzykrotnie większa niż dla ziaren o większych rozmiarach. Im mniejszy rozmiar ziaren, tym większa powierzchnia zewnętrzna zeolitu ulegająca modyfikacji. To z kolei przekłada się na większą efektywność sorpcji anionów Cr(VI.).

\subsection{Wpływ rodzaju materiału zeolitowego na efektywność sorpcji $\mathrm{Cr}(\mathrm{VI})$}

Badanie wpływu rodzaju materiału na efektywność sorpcji Cr(VI), przeprowadzono dla chabazytu oraz filipsytu o wielkości uziarnienia $<0,25 \mathrm{~mm}$, przy początkowym odczynie $\mathrm{pH}$ roztworów wodnych równym 4,0 oraz zakresie stężeń $\mathrm{Cr}(\mathrm{VI})$ od 0,5 do $1500 \mathrm{mg} / \mathrm{dm}^{3}$. 


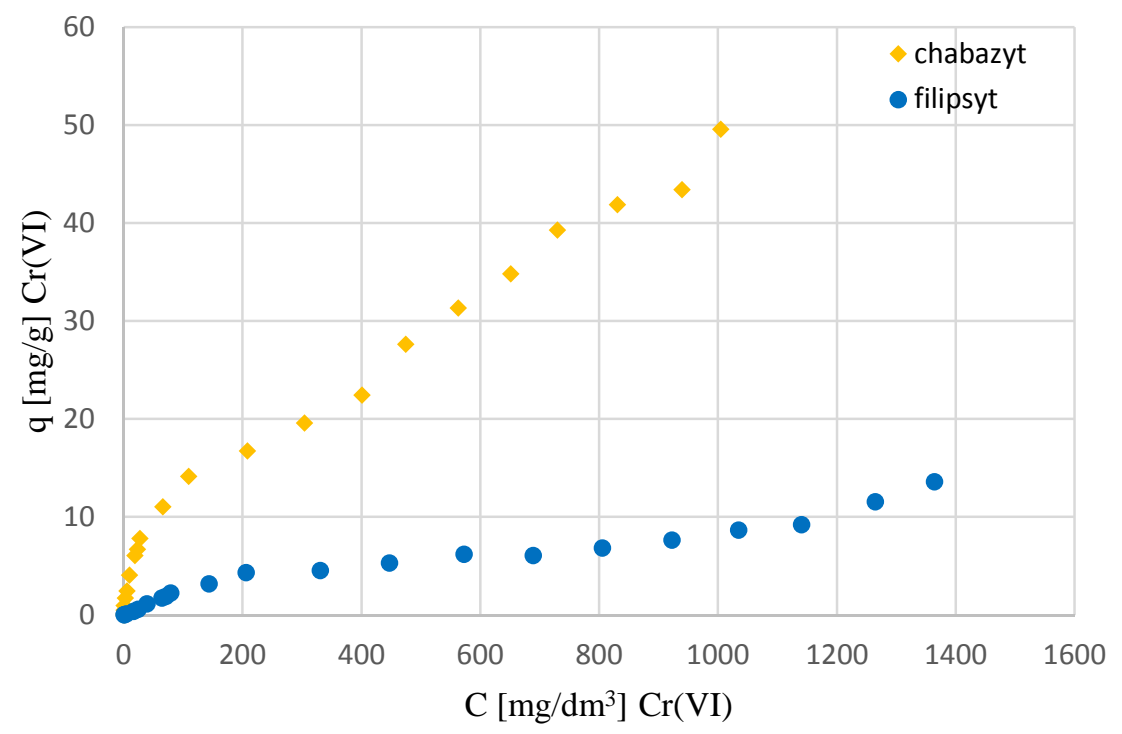

Rys. 2. Wpływ rodzaju materiału na efektywność sorpcji Cr(VI)

Fig. 2. Influence of type of material on the effectiveness of the sorption of $\mathrm{Cr}(\mathrm{VI})$

Na rysunku 2 można zauważyć, że efektywność sorpcji dla chabazytu jest większa w każdym punkcie w porównaniu do filipsytu. Uzyskana maksymalna pojemność sorpcyjna chabazytu $(49,61 \mathrm{mg} / \mathrm{g})$ jest prawie czterokrotnie większa niż dla filipsytu $\left(\mathrm{q}_{\mathrm{m}, \mathrm{xp}}=13,61 \mathrm{mg} / \mathrm{g}\right)$. W zależności od pochodzenia zeolity mogą charakteryzować się różną strukturą, wielkością i objętością porów sorpcyjnych oraz powierzchnią właściwą [3]. Sorpcja HDTMA-Br na zeolicie odbywa się tylko na zewnętrznej powierzchni wymiennej w miejscach łatwo dostępnych dla cząsteczek o dużych rozmiarach. Tak więc wielkość zewnętrznej pojemności kationowymiennej (ECEC) decyduje o ilości zaadsorbowanego środka powierzchniowo czynnego. Chabazyt o większej ECEC $(0,2625 \mathrm{mmol} / \mathrm{g})$ efektywnej niż filipsyt $(0,1174 \mathrm{mmol} / \mathrm{g})$ sorbował jony $\mathrm{Cr}(\mathrm{VI})$.

\subsection{Wpływ odczynu pH roztworu na efektywność sorpcji Cr(VI)}

Badanie wpływu pH roztworu na efektywność sorpcji przeprowadzono dla filipsytu oraz chabazytu o wielkości uziarnienia $<0,25 \mathrm{~mm}$. Zakres stężeń roztworów $\mathrm{Cr}(\mathrm{VI})$ mieścił się w przedziale od 0,5 do $750 \mathrm{mg} / \mathrm{dm}^{3}$. Natomiast, odczyn $\mathrm{pH}$ roztworów był równy 3,0; 4,0 oraz 5,0. 


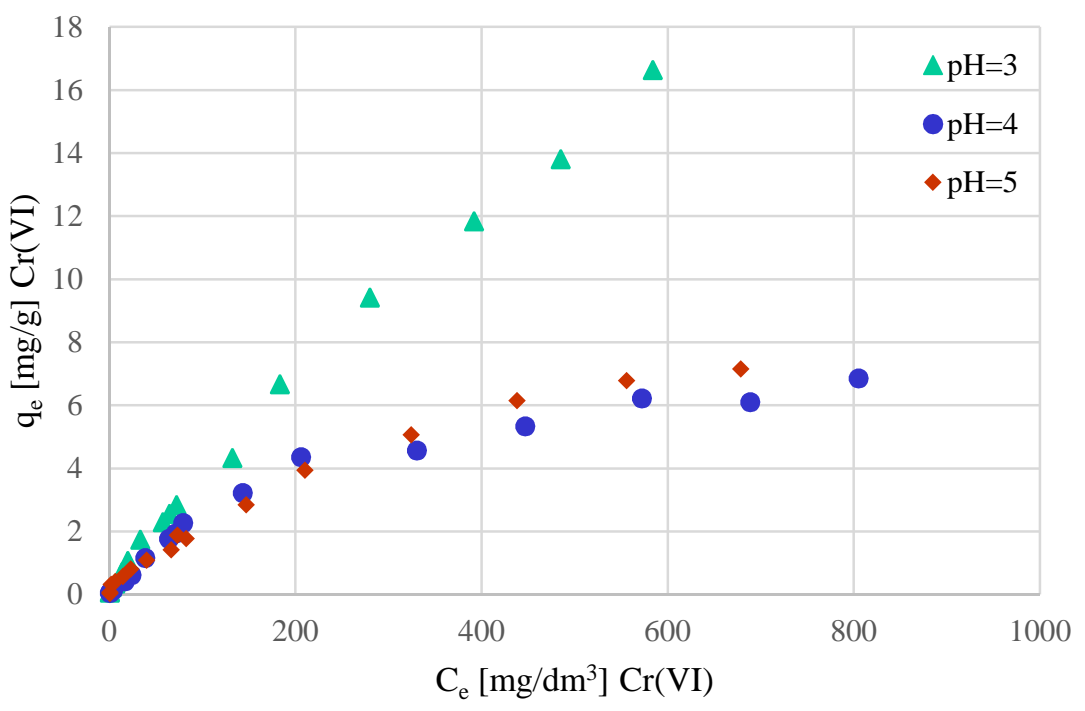

Rys. 3. Wpływ odczynu pH na efektywność sorpcji Cr(VI) na filipsycie

Fig. 3. Influence of the reaction $\mathrm{pH}$ on the effectiveness of the sorption of $\mathrm{Cr}(\mathrm{VI})$ on the phillipsite

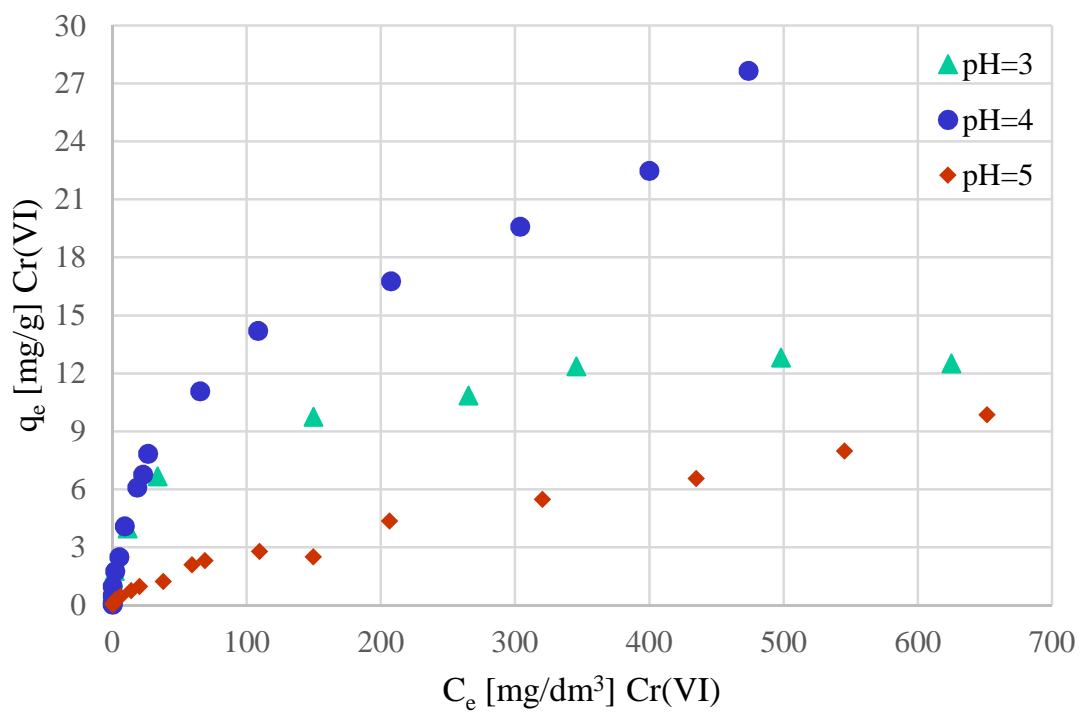

Rys. 4. Wpływ odczynu pH na efektywność sorpcji Cr(VI) na chabazycie

Fig. 4. Influence of the reaction $\mathrm{pH}$ on the effectiveness of the sorption of $\mathrm{Cr}(\mathrm{VI})$ on the chabazite 
Wyniki badań zamieszczone na rys. 3 i 4 wskazują, że sorpcja związków $\mathrm{Cr}(\mathrm{VI}) \mathrm{z}$ roztworów wodnych przez zeolity modyfikowane HDTMA-Br jest w znacznym stopniu zależna od pH roztworu, które ma wpływ na skład chemiczny sorbowanych związków, ładunek powierzchniowy i stopień jonizacji sorbentu $[2,9]$. Efektywność sorpcji anionów $\mathrm{Cr}(\mathrm{VI})$ na filipsycie (rys. 3) jest największa dla roztworu o początkowym odczynie $\mathrm{pH}$ równym 3,0. Przy niskich stężeniach nieznacznie odbiega od pozostałych, ale dla wyższych stężeń jest znacznie większa. Natomiast dla roztworów o $\mathrm{pH}_{\text {init }}=4,0$ i 5,0, sorpcja jest na podobnym poziomie. Maksymalne pojemności sorpcyjne otrzymane eksperymentalnie $\left(\mathrm{q}_{\mathrm{m}, \exp }\right)$, przy największym stężeniu roztworu chromu, wynosiły odpowiednio 16,65, 7,30 oraz $6,23 \mathrm{mg} / \mathrm{g}$, dla początkowego $\mathrm{pH}$ równego 3,0, 5,0 i 4,0.

Sorpcja Cr(VI) na chabazycie przebiegała efektywniej. Jak widać na rysunku 4 , największą efektywność otrzymano dla $\mathrm{pH}_{\text {init }}=4,0$, następnie dla $\mathrm{pH}_{\text {init }}=3,0$, a najniższą dla $\mathrm{pH}_{\text {init }}=5,0$. Przy niskich stężeniach, do wartości około $30 \mathrm{mg} / \mathrm{dm}^{3}$, sorpcja $\mathrm{Cr}(\mathrm{VI}) \mathrm{z}$ roztworów o $\mathrm{pH}_{\text {init }}=4,0$ i 3,0 była porównywalna $\left(5,01\right.$ i $\left.4,9 \mathrm{mg} / \mathrm{dm}^{3}\right)$, natomiast powyżej $50 \mathrm{mg} / \mathrm{dm}^{3}$ sorpcja dla $\mathrm{pH}=4,0$ była już wyższa $(8,99$ i $10,76 \mathrm{mg} / \mathrm{dm}^{3}$ ). Ściślej sorpcja dla $\mathrm{pH}=4,0$ była znacznie większa od pozostałych, przy wyższych stężeniach. Maksymalne pojemności sorpcyjne, przy największym stężeniu, wynosiły odpowiednio $27,68,12,83$ oraz 9,88 , dla początkowego $\mathrm{pH}$ równego 4,0, 3,0 i 5,0.

W środowisku wodnym, chrom (VI) może występować w różnych formach jonowych. Obecność związków Cr(VI) zależy zarówno od stężenia jak i pH roztworu w stanie równowagi. $\mathrm{Cr}(\mathrm{VI})$ przy $\mathrm{pH}<1$ tworzy kwas chromowy, $\mathrm{H}_{2} \mathrm{CrO}_{4}$. W miarę spadku kwasowości w roztworze pojawiają się produkty jego hydrolizy: jony wodorochromianowe $\mathrm{HCrO}_{4}^{-}$oraz chromianowe $\mathrm{CrO}_{4}{ }^{2-}$. W zakresie $\mathrm{pH}$ od 1 do 6 , przy stężeniu chromu (VI) przekraczającym $0,6 \mathrm{mg} / \mathrm{dm}^{3}$, jony wodorochromianowe $\mathrm{HCrO}_{4}^{-}$podlegają kondensacji z utworzeniem jonów dwuchromianowych $\mathrm{Cr}_{2} \mathrm{O}_{7}{ }^{2-}$.

W wyniku przeprowadzonych badań eksperymentalnych dotyczących sorpcji $\mathrm{Cr}(\mathrm{VI}) \mathrm{w}$ odpowiednich warunkach $\mathrm{pH}$ i stężenia sorbowanych roztworów filipsyt uzyskał najefektywniejszą sorpcję dla całego zakresu stężeń przy $\mathrm{pH}=3$, natomiast chabazyt dla $\mathrm{pH}$ równego 4,0. W takich warunkach $\mathrm{pH}$, związki chromu (VI) występują w takich samych formach i prawie takich samych ilościach. Wobec tego, można stwierdzić, że każdy rodzaj materiału użyty do badań ma swoje optymalne $\mathrm{pH}$, przy którym najlepiej sorbuje związki Cr(VI) niezależnie od ich stężenia.

\subsection{Modelowanie procesu sorpcji $\mathrm{Cr}(\mathrm{VI})$}

Obliczenia modelowe przeprowadzono dla sorpcji na modyfikowanym chabazycie i filipsycie o wielkości uziarnienia $<0,25 \mathrm{~mm} \mathrm{z}$ roztworów wodnych $\mathrm{Cr}(\mathrm{VI})$ o stężeniu w przedziale od 0,5 do $750 \mathrm{mg} / \mathrm{dm}^{3}$ przy $\mathrm{pH}=3$ dla chabazytu i $\mathrm{pH}=5$ dla filipsytu. Do obliczeń użyto standardowe równania empiryczne zaczerpnięte $\mathrm{z}$ literatury tematu (model Langmuira, Freundlicha i Langmuira- 
Freundlicha) $[18,5]$. Obliczenia modelowe przeprowadzono metodą nieliniowej regresji z wykorzystaniem algorytmu Levenberga-Marquardta w programie komputerowym Maple 15. Do oceny jakości dopasowania użyto czterech funkcji statystycznych: testu Fisher'a (TF), aproksymacji odchylenia standardowego (S), współczynnika determinacji $\left(\mathrm{R}^{2}\right)$ oraz błędu średniego (ME) [16].

Wyniki obliczeń modelowych wraz $\mathrm{z}$ wartościami testów statystycznych zestawiono w tabeli 1. Analiza zamieszczonych wartości wskazuje, że w przypadku maksymalnej pojemności sorpcyjnej $\left(\mathrm{q}_{\mathrm{m}}\right)$, obliczonej na drodze modelowania, w porównaniu do wartości eksperymentalnej $\left(\mathrm{q}_{\mathrm{m}, \mathrm{exp}}\right)$, najlepsze dopasowanie dla filipsytu otrzymano dla trzy-parametrowej izotermy Langmuir-Freundlich, natomiast dla chabazytu dla dwu-parametrowej izotermy Langmuir'a. Biorąc pod uwagę wartości testów statystycznych, najlepiej dopasowana okazała się izoterma Langmuir-Freundlich.

Tabela 1. Wartości parametrów modeli i testów statycznych

Table 1. The values of model parameters and static tests

\begin{tabular}{|l|c|c|c|c|c|}
\hline Model & $\begin{array}{c}\mathbf{q m} \\
{[\mathrm{mmol} / \mathrm{kg}]}\end{array}$ & $\begin{array}{c}\text { TF } \\
{[-]}\end{array}$ & $\begin{array}{c}\text { ME } \\
{[\%]}\end{array}$ & $\begin{array}{c}\text { S } \\
{[-]}\end{array}$ & $\begin{array}{c}\mathbf{R}^{\mathbf{2}} \\
{[-]}\end{array}$ \\
\hline Sorpcja na filipsycie & 11,82 & 211,15 & 28,81 & 0,17 & 0,995 \\
\hline Langmuir & & 112,00 & 22,91 & 0,24 & 0,991 \\
\hline Freundlich & 14,03 & 215,06 & 26,41 & 0,17 & 0,995 \\
\hline Langumir-Freundlich & \multicolumn{5}{|l|}{} \\
\hline Sorpcja na chabazycie \\
\hline Langmuir & 12,87 & 42,34 & 22,65 & 0,75 & 0,979 \\
\hline Freundlich & 44,47 & 21,59 & 0,73 & 0,980 \\
\hline Langmuir-Freundlich & 16,91 & 136,22 & 14,34 & 0,42 & 0,994 \\
\hline
\end{tabular}

Porównanie danych eksperymentalnych i modelowych przedstawiono graficznie na rysunku 5. Analiza przebiegu krzywych modelowych wskazuje, że dopasowanie obliczonych izoterm sorpcji, do danych eksperymentalnych dla filipsytu, było dobre z wyjątkiem izotermy Freundlich'a (rys. 5A). Dla chabazytu najlepsze dopasowanie otrzymano dla izotermy Langmuir-Freundlich (rys. 5B).

Mając na uwadze wszystkie te kryteria, izotermą o najlepszym dopasowaniu zarówno dla filipsytu jak i chabazytu jest izoterma Langmuir-Freundlich. 
A

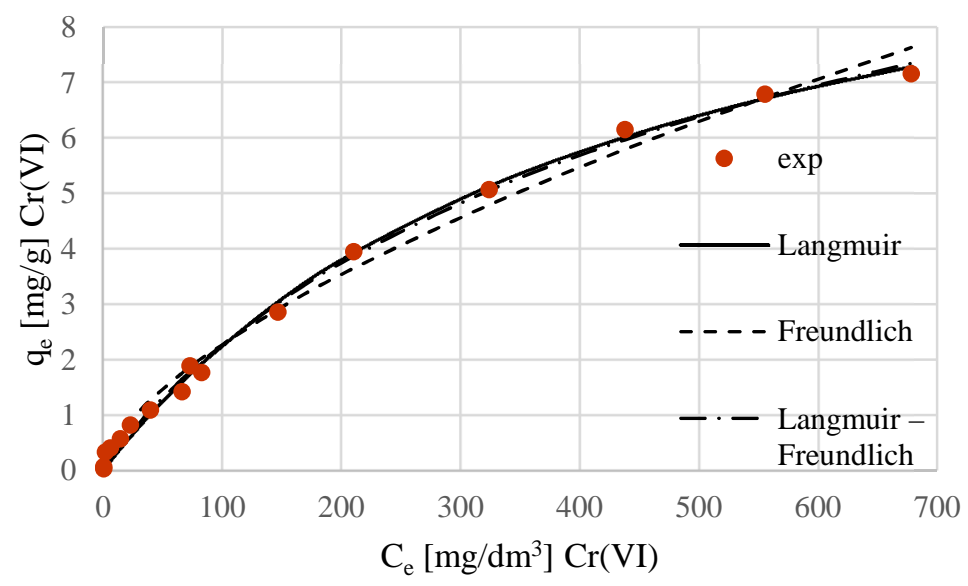

B

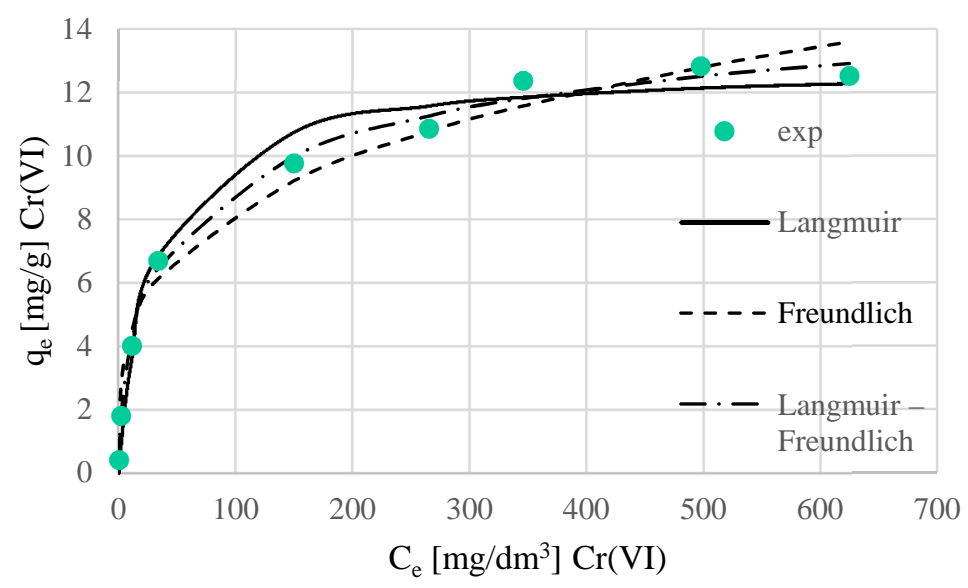

Rys. 5. Porównanie danych eksperymentalnych z krzywymi modelowymi sorpcji $\mathrm{Cr}(\mathrm{VI})$ na (A) filipsycie i (B) chabazycie

Fig. 5. Comparison of experimental data and modeling isoterms of $\mathrm{Cr}(\mathrm{VI})$ sorption on (A) phillipsite $i(B)$ chabazite

Jednakże podsumowując otrzymane wyniki, można wywnioskować, że żadna z izoterm nie spełnia wszystkich warunków dopasowania, a więc nie odzwierciedla w sposób matematyczny wszystkich zjawisk zachodzących podczas sorpcji $\mathrm{Cr}(\mathrm{VI})$ na modyfikowanym HDTMA-Br chabazycie oraz filipsycie. 


\section{Wnioski}

Rezultatem chemicznej modyfikacji naturalnych zeolitów jest uzyskanie efektywnego sorbentu jonów $\mathrm{Cr}(\mathrm{VI})$.

W wyniku przeprowadzonych badań stwierdzono, że sorpcja chromu (VI) przebiega najskuteczniej na chabazycie, gdy proces prowadzony jest $\mathrm{z}$ roztworu o $\mathrm{pH}=4$, natomiast dla filipsytu przy $\mathrm{pH}=3$.

Przeprowadzone badania wykazały, że mniejszy rozmiar cząstek materiału powoduje znaczącą poprawę efektywności sorpcji Cr(VI), ze względu na większą powierzchnię którą posiada, dzięki czemu może się poprawić jego zewnętrzna efektywność kationowymienna (ECEC), a w związku z tym ilość naniesionego HDTMA-Br podczas modyfikacji.

Istotnym czynnikiem, który ma również wpływ na efektywność sorpcji $\mathrm{Cr}(\mathrm{VI})$ jest rodzaj zeolitu. Podczas wyboru naturalnego materiału zeolitowego do modyfikacji HDTMA-Br, należy się kierować jego właściwościami, a szczególnie zewnętrzną pojemnością kationowymienną (ECEC), która w główniej mierze wpływa na załadunek HDTMA-Br podczas modyfikacji i późniejszą sorpcję.

Sorpcja $\mathrm{Cr}(\mathrm{VI})$ na modyfikowanych HDTMA-Br zeolitach naturalnych zależna jest od pH i stężenia roztworu. Sorpcja przy niskim odczynie pH jest największa, jednak każdy zeolit może mieć swoją optymalną wartość pH. Powyżej pH równego 5 sorpcja zaczyna się obniżać niezależnie od rodzaju materiału, ze względu na formy i ilości związków Cr(VI), jakie występują w tych warunkach.

Jak do tej pory nie opracowano jeszcze równania izotermy, które dokładnie opisywałoby proces sorpcji Cr(VI). Niemniej jednak można posłużyć się niektórymi równaniami do przybliżonego opisu tego procesu. Wybór równania zależy od dopasowania obliczonych wartości modelowych do wartości eksperymentalnych, należy rozważyć różne równania izoterm, ponieważ dla każdego przypadku może być odpowiednie inne równanie.

\section{Literatura}

[1] "ToxFAQs: Chromium". Agency for Toxic Substances \& Disease Registry, Centers for Disease Control and Prevention. February 2001. Archived from the original on 2014-07-08. Retrieved 2007-10-02.

[2] Benaissa H., Benguella B., Cadmium removal from aqueous solutions by chitin: kinetic and equilibrium studies, Water Res. 36 (2002) 2463-2474.

[3] Ciciszwili G.W., Andronikaszwili T.G., Kirow G.N., Filizowa L.D., Zeolity Naturalne, Wydawnictwa Naukowo-Techniczne, Warszawa $1990 \mathrm{r}$.

[4] Drozd M., Warchoł J.. Sorbenty stosowane do usuwania Cr(VI) z roztworów wodnych. Czasopismo Inżynierii Lądowej, Środowiska i Architektury - Journal of Civil Engineering, Environment and Architecture, JCEEA, t. XXX, z. 60 (4/13), 2013, s. 5-19, DOI: $10.7862 / \mathrm{rb} .2013 .54$.

[5] Grace M. Haggerty and Robert S. Bowman. Sorption of Chromate and Other Inorganic Anions by Organo-Zeolite. Environmental Science \& Technology 1994, 28, 452-458. 
[6] Mertz, Walter (1 April 1993). Chromium in Human Nutrition: A Review. Journal of Nutrition 123 (4): 626-33.

[7] Mohana D., Pittman Jr. C. U.;Activated carbons and low cost adsorbents for remediation of tri- and hexavalent chromium from water.; Journal of Hazardous Materials B137 (2006) 762-811.

[8] Nriagu J.O.: Production and uses of chromium. Chromium in the natural and human environments. John Wiley \& Sons, New York, no 1988, pp. 81-103.

[9] Nuñez R.L.F., Estudio preliminar de approve chamiento de hueso de aceituna para biosorción de cadmio. Trabajo de Investigación, Departamento de Ingeniería Química, Universidad de Granada, Granada, España 25 (2004) 36-39.

[10] Papp, John F. \& Lipin, Bruce R. (2006). "Chromite". Industrial Minerals \& Rocks: Commodities, Markets, and Uses (7th ed.). SME. 309-334.

[11] Rozporządzenie Ministra Środowiska z dnia 24 lipca 2006 r. w sprawie warunków, jakie należy spełnić przy wprowadzaniu ścieków do wód lub do ziemi, oraz w sprawie substancji szczególnie szkodliwych dla środowiska wodnego(Dz. U. z dnia 31 lipca 2006 r.) Dz.U. 2006.137.984.R4.

[12] Rozporządzenie Ministra Środowiska z dnia 27 listopada 2002 r. w sprawie wymagań, jakim powinny odpowiadać wody powierzchniowe wykorzystywane do zaopatrzenia ludności w wodę przeznaczoną do spożycia. (Dz. U. Nr 204, poz. 1728).

[13] Rozporządzenie Ministra Zdrowia z dnia 20 kwietnia 2010r. zmieniające rozporządzenie w sprawie jakości wody przeznaczonej do spożycia przez ludzi Na podstawie art. 13 ustawy z dnia 7 czerwca 2001 r. o zbiorowym zaopatrzeniu w wodę i zbiorowym odprowadzaniu ścieków (Dz. U. z 2006 r. Nr 123, poz. 858, z 2007 r. Nr 147, poz. 1033 oraz z 2009 r. Nr 18, poz. 97).

[14] Sarin V., Sarvinder Singh T., K.K. Pant. Thermodynamic and breakthrough column studies for the selective sorption of chromium from industrial effluent on activated eucalyptus bark. Bioresource Technology 97 (2006) 1986-1993.

[15] Sharma Y. C., Srivastava V., Singh V. K., Kaul S. N. and Weng C. H.,"NanoAdsorbents for Removal of Metalic Pollutants from Water and Wastewater," Environmental Technology, Vol. 30, No. 6, 2009, pp. 583-609.

[16] Sobczyk M. Statystyka. PWN, Warszawa 2007.

[17] Vincent John B. (2013). Chapter 6. Chromium: Is It Essential, Pharmacologically Relevant, or Toxic?. In Astrid Sigel; Helmut Sigel; Roland K. O. Sigel. Interrelations between Essential Metal Ions and Human Diseases. Metal Ions in Life Sciences 13. Springer. pp. 171-198.

[18] Yusof A.M., Malek N.A. Removal of $\mathrm{Cr}(\mathrm{VI})$ and $\mathrm{As}(\mathrm{V})$ from aqueous solutions by HDTMA-modified zeolite Y. Journal of Hazard Materials 162(2-3) (2009) 1019-1024.

[19] Zayed AM, Terry N (2003) Chromium in Environment: Factors affecting biologic remediation. Plant Soil 249:135-156. 


\section{SORPTION OF CHROMIUM (VI) ON MODIFIED NATURAL ZEOLITES}

\section{S u m m a r y}

The objective of the study was to determine the equilibrium of sorption of ions of chromium (VI) from aqueous solutions on modified natural zeolites from Italy and the USA. For the synthesis of organo-zeolite HDTMA-Br was used in an amount twice the cation exchange capacity of zeolite (2.0 ECEC). The studies were conducted under static at a $\mathrm{pH}$ of 3.0; 4.0 and 5.0 at room temperature. The highest sorption efficiency of $\mathrm{Cr}(\mathrm{VI})$ was obtained for chabazite at $\mathrm{pH}=4$ and grain size below $0.25 \mathrm{~mm}$ when the solution was dominated by the hydrogen chromate ions $\mathrm{HCrO}_{4}$.

Keywords: sorption, modification, zeolites, organo-zeolites, chromium (VI), HDTMA

Przestano do redakcji: $24.09 .2016 r$.

Przyjęto do druku: 31.03.2017 r. 